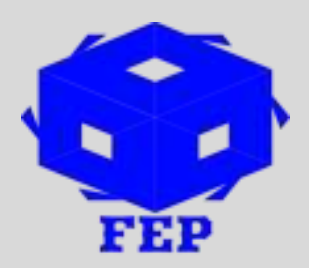

\title{
AN EMPIRICAL INVESTIGATION INTO THE RELATIONSHIP BETWEEN PREMIUMS AND CLAIMS PAID IN THE NIGERIAN INSURANCE INDUSTRY: A 2000-2017 ANALYSIS
}

\author{
Ukpong, Mfon Sampson \\ Department of Insurance, University of Uyo, Akwa Ibom State
}

*Corresponding Author: Upkong, Mfon, Sampson

Corresponding Author Email: mfonukpong@ rocketmail.com

Article Received: 21-03-19 Accepted: 31-03-19 Published: 05-04-19

Licensing Details: Author retains the right of this article. The article is distributed under the terms of the $\begin{array}{lllll}\text { Creative } & \text { Commons } & \text { Attribution-NonCommercial } & 4.0 & \text { Licence }\end{array}$ (http://www.creativecommons.org/licences/by-nc/4.0/) which permits non-commercial use, reproduction and distribution of the work without further permission provided the original work is attributed as specified on the Journal open access page.

\begin{abstract}
This study is an investigation into the relationship between premiums received and claims paid in the Nigerian insurance industry over the period 2000-2017. Data on gross premiums received and gross claims paid over the period were gotten from the Central Bank of Nigeria (CBN) statistical bulletin, National Insurance Commission (NAICOM) and the Nigerian Insurers Association (NIA) annual reports. Stationarity test carried out on the data reveal that data is stationary at the $1 \%, 5 \%$ and $10 \%$ levels of significance. The cointegration test reveals that no cointegration exists among the variables which imply that there is no long run equilibrium relationship between the variables. Using the ordinary least squares regression, the calculated probability value of 0.167 is higher than the 0.05 significant value, hence we accept the null hypothesis that there is no significant relationship between claims paid and premiums received in the Nigerian insurance industry. The coefficient of determination $\left(\mathrm{R}^{2}\right)$ of 0.91157 indicates that gross premiums contribute 91.2 percent to variations in gross claims while the remaining 8.6 percent is owing to factors outside the regression model. We therefore conclude that claims paid by insurers is not a function of premiums received and recommend that insurers should endeavour to settle claims promptly and equitably to increase client satisfaction.
\end{abstract}

Keywords: Premiums, Claims, Nigeria 


\section{INTRODUCTION}

Many authors have provided various definitions of insurance over the years. Isimoya (2007) defines Insurance as a social scheme which provides financial compensation for the effects of a misfortune or a promise for compensation for specific potential future losses in exchange for a periodic payment. Fofi, (2016) defines Insurance as a risk transfer mechanism whereby risk is pooled from a large number of people and financial compensation is provided for the few people to whom the insured-against event occurs. In exchange of payments from the insured called premium, the insurer agrees to pay the policyholder a sum of money upon the occurrence of a specific event. Insurance is considered one of the financial risk management strategies that can help individuals and societies deal with risk effectively (Ukpong and Acha, 2017).

From the various definitions of insurance proffered, it can be deduced that there are certain key elements or parameters which make up the concept of insurance. These include: the possibility of adverse random events (Epetimehin and Ekundayo 2012), the consideration which is the premium paid for the cover (Fiedler, 2018; Ramos, 2017), ability to make reasonable estimate of future losses by the insurer (Harrington and Niehaus 2006); and indemnification otherwise referred to as claim settlement (Amoroso, 2011), which is the payment for losses actually incurred. Perhaps the insurance concept can be better explained as a form of organized protection against financial loss. Through this mechanism, a large number of persons share losses. Each insured person pays a small sum known as the premium in return for the insurance protection given by the insurer. The effect of this arrangement is that each financial loss that may occur is spread over the large number of persons or policy holders protected under the programme. It can therefore be stated that the basic function of insurance is to offer protection against financial loss to the insured person (Butler and Francis, 2010; Hartwig and Wilkinson, 2010; Smith, 2013)

\section{Problem Statement}

Claim settlement is an indispensable aspect of insurance business which is often described as the functional life blood of any insurance company. Commercially, they represent by far, the largest single cost to insurers. Butler and Francis (2010) assert that claims settlement is the pivot on which the wheels of the entire industry rotate. The claim settlement can be considered as defining moment of relationship between insurer and its customer. However, a lot of time, the way insurance companies handle insurance claims is not appropriate. Sadly however, cases of unsettled claims still abound in the Nigerian insurance industry. Reasons for such scenario range from faults from the insured such as fraudulent claims, attempts by the insurer to desist from paying exorbitant claims, to undue legal tussle between the insured and the insurer in the claim payment process (Michael, 2008; Yusuf and Dansu, 2014). Arising from the increasing complaints on non-settlement of claims by Nigerian insurers coupled with the dearth of data on claim settlement trends in Nigeria, it becomes expedient to know the relationship between premiums and claim expenses in the Nigerian insurance industry. There is also a need to investigate whether the premiums received by these companies is appropriate to settle anticipated 
claims and to empirically show the effect of an increase or decrease in premium income on claim expenses. This is thus the problem this study seeks to investigate.

\section{Objective/Significance Of Study}

The major purpose of this paper is to analyse the relationship between gross insurance gross claims paid and premiums received over the period 2000 - 2017. It aims at examining the significance and suitability of premium income received by insurance companies as regards the settlement of claims. The outcome of this study will bring to light the challenges faced by insurers in settling claims and would help to resolve the paradigm of no/delays in claim settlement by Nigerian insurers. It will be of immense significance to the insurance industry as it will make them reconsider the premium setting model to ensure it effectively makes provision for attendant claims. Such model will be of help in determining the level of premium that should be charged to make allowance for effective claim settlement. The study hypothesis is that gross insurance claim is significantly related to gross premium over the study period (2000-2017). This study paper is sectionalized into introduction, problem statement, literature review, methodology, analysis of data, discussion, conclusion and recommendation.

\section{LITERATURE REVIEW}

One of the basic requirements of an insurance contract is the premium which serves as the consideration (Ramos, 2017; Ukpong and Acha, 2017; Fiedler, 2018). Without this consideration, there is no cover. Diacon (1983); Harrington and Niehaus (2006) and Epetimehin and Ekundayo (2012) possess this opinion that a fair premium is one which can easily cover claim cost, underwriting expenses, administrative expenses, and a suitable profit. Dansu and Yusuf (2014) conducted an observation of insurance companies financial statement during the period of 2007 and 2011 and showed that companies claim payment was major part of premium income.

\section{Empirical Review}

According to the study carried out by Agbamuche (2012) on investment of insurance funds in the Nigerian capital market, it was discovered that premium incomes form the major source of funds available to the insurance industry. Dansu and Yusuf (2014) opine that claim cost calculation is based on total losses incurred by an insurer and including any adjustment expenses. Furthermore, in connection with premium, the loss ration is about total paid or reserved losses made in relation to claims plus adjustment expenses and divided by total premium earned. A higher loss ratio could indicate poor risk selection. Harrrington and Niehaus (2006), Amoroso (2012) in Dansu and Yusuf (2014) and Fiedler (2018) in their research discover that the cost of claim pay-outs and expenses is the largest spending category for an insurer, accounting for up to $80 \%$ of premium income.

In a research carried out by Risto, Donham, Sprince, Reynolds, Philips and Zwerling (2005) on the relationship between changes in injury claim rates and premium discount, it was observed 
that the premium discount decreased the overall claim rate. The pattern suggested that underreporting contributed to the decrease though it was not the only contributing factor. The value of the premium discount was found to be lower than the value of a lost-time claim, so there was no financial reason to under-report lost-time injuries. This is in line with the research conducted by Ramos (2017) and Fiedler (2018). Chandra, Nundy and Seabury (2005) in Reich and Schatzberg (2015) found that premiums charged by malpractice insurers may be influenced by factors that have nothing to do with claims paid out. They point out that the decline in insurer's investment income may be influenced by such non-medical factors like interest rates and premiums charged. Therefore, premiums could reflect changes in investment income, not just the changes in malpractice payouts.

\section{Theoretical Review}

Premium calculation principle is a very important aspect of actuarial operations. Most theoreticians in this field believe that the insurance premium should reflect both the expected claims and loading. Three types of loadings are mostly recognized - risk by the insurer while underwriting the policy, covering profit, and commission, administrative, and claim settlement expenses. The insurer's ratemaking decision therefore depends on his ability to estimate the expected claims (including costs) and on the selection of a fair risk loading (Kahane, 1979). According to Buhlmann (1970), four possible pirnciples of risk loading are presence of constant utility, variance loading, standard deviation loading, and expected value principle.

A viable theory on premiums and claims is the theory of Insurance Premiums as promulgated by Arrow (1953) based on the capital asset price model. This theory was further analysed by Sharpe (1964), Lintner (1965) and Mossin (1966). The theory postulates that the payment of premium and the recovery of a random amount as settlement of claims is akin to that of the purchase of a share in a risky business. The price of such shares is presumably determined by the supply and demand in the market, as are insurance premiums and claims (Ramos, 2017). Although this is generally acceptable, actuaries however believe the model used for the theory is a one-period model depending only on expectation and variance and is too primitive for the purpose intended. Hence, they develop an actuarial theory of risk which places the focus on a class of stochastic process in continuous time (Borch, 1985; Fiedler, 2018).

\section{Research Design}

\section{METHODOLOGY}

The aim of this study is to examine the relationship between gross insurance premiums received by insurance companies and gross claims paid out over the period $2000-2017$. The ex-postfacto research design is adopted. Data is sourced from the Central Bank of Nigeria (CBN) statistical bulletin, NAICOM annual report and the Nigerian Insurers Digest all spanning over the period 2000-2017. Data is analysed using the Augmented Dicker Fuller unit root test and Johnson Co-integration technique. T-test from the ordinary least square regression analysis is adopted in testing the hypothesis. 
The functional model for the study is specified as:

$\mathrm{GCP}=\mathrm{F}\left(\mathrm{GPI}+\mathrm{u}_{\mathrm{t}}\right)$

When expressed in an econometric form, it is presented as:

$\mathrm{GCP}=\mathrm{b}_{0}+\mathrm{b}_{1} \mathrm{GPI}+\mathrm{u}_{\mathrm{t}}$

Where GCP = gross claims paid, and

$\mathrm{GPI}=$ gross premiums received

$b_{0}$ - is a constant parameter; $b_{1}$ is an explanatory variable and $\mu_{t}$ is the stochastic error term. They are usually included in a standard time series specification to account for the omitted variables as well as unexplained random effects within the model.

\section{Test For Stationarity}

\section{RESULTS AND DISCUSSION}

The Augmented Dicker-Fuller test is adopted in testing for stationarity of the time series data. This is to avoid the occurrence of spurious results in the data. The results are presented in table 2. The analysis shows the result of the unit root test (Stationarity test) carried out at $1^{\text {st }}$ difference with a maximum lag of 3. The results indicate that both GCP and GPI have a unit root. Since the t-statistic is less than the probability for both GCP and GPI, the data is considered stationary and can be relied on for research purposes. Additionally, the t-statistic value of the ADF model is less than the critical values at $1 \%, 5 \%$ and $10 \%$ which implies the absence of shocks in the model. This result also indicates that all the variables can be linearly combined with each other.

\section{Test For Cointegration}

The Johansen cointegration test is conducted to determine whether there exists long run equilibrium relationship among the variables in the study. Our result seems to indicate that no cointegration exists among the variables as the trace statistic is significantly less than the critical value at the 0.05 critical level. This implies that there is no long run equilibrium relationship between GCP and GPI, hence the variables are likely to wander away from each other endlessly and may never return to an equilibrium path. The maximum eigenvalue test also seems to be in support of this notion as the max-eigenvalue statistic is less than the critical value at the 95 percent confidence level. Thus, we fail to reject the hypothesis of no cointegrating relationship among the variables.

\section{Regression Analysis}

A simple regression analysis is conducted to test the linear relationship that exists between the variables. From our computation, it can be observed that the calculated p value seems to be greater than the 0.05 benchmark. Hence we accept the null hypothesis and maintain that there is no significant relationship between gross claims paid and gross premiums received 
in the Nigerian insurance industry. This is in line with studies carried out by Chandra, Nundy and Seabury (2005) and Reich and Schatzberg (2015) where they discovered that premiums charged by insurers are influenced by factors that have nothing to do with claims paid out.

Similarly, a regression coefficient of -9339.65 indicates a negative and an indirect relationship between the variables. The coefficient of determination $\left(\mathrm{R}^{2}\right)$ which is 0.91157 indicates that gross premiums contribute 91.2 percent to variations in gross claims while the remaining 8.6 percent is owing to factors outside the regression model. An F-statistic of 164.9 which is significantly greater than the Prob (F-statistic) indicates that the model has a good fit. The computation also reveals a Durbin Watson statistic of 2.04. This is higher than the tabulated Durbin Watson figures of $\mathrm{d}_{\mathrm{L}}=1.08$ (lower limit) and $\mathrm{d}_{\mathrm{U}}=1.28$ (upper limit). Hence we reject the null hypothesis that there is no positive autocorrelation in the residuals.

\section{CONCLUSION AND RECOMMENDATION}

This study was carried out to explore the relationship between claims paid and premiums received in the Nigerian Insurance industry over the period 2000-2017. Data was sourced from Central bank of Nigeria (CBN) statistical bulletin, National Insurance Commission (NAICOM) annual report and the Nigerian Insurers Digest covering the selected years. Data was subjected to various empirical tests and the results from the linear regression test seem to reveal that there is no significant relationship between claims paid and premiums received in the Nigerian Insurance Industry. This implies that the claims paid out by insurers is not a function of the premiums they receive. Also, premiums only contribute about 91.2 percent of the variations in claims while the remaining percentage is contributed by other factors.

It is therefore recommended that the Nigerian insurance industry should ensure prompt settlement of claims as claim settlement is not necessarily a factor of the premium received. Additionally, genuine claims must be settled equitably in order to earn the confidence of the insuring public. Moreover, insurers should undertake regular researches on claims settlement in order to enable them recognise and adopt better approaches to the subject capable of increasing client satisfaction.

\section{References}

Agbamuche, U. (2012) Investment of Insurance Funds in the Nigerian Capital Market. www.dare.uva.nl/document $/ 358477$

Amoroso, C. (2011) Driving Operational Excellence in Claims Management. Retrieved from http://www.deloitte.com

Arrow, K. (1953) The Role of Securities in the Optimal Allocation of Risk Bearing. Review of Economic Studies, 31, $91-96$

Bates, I. \& Atkins, D. (2007) Risk Regulation and Capital Adequacy. CIIN Study Course A510

Borch, K. (1985) A Theory of Insurance Premiums. The Geneva Papers on Risk and Insurance, 10 (36) $192-208$

Brooks, P., Popow, D. \& Hoopes, D. (2005) Introduction to Claims. USA: American Institute for Chartered Property Casualty Underwriters, Incorporated

Buhlmann, H. (1970) The Mathematical Methods in Risk Theory. Berlin: Springer Verlag.

Butler, S. \& Francis, P. (2010) Cutting the Cost of Insurance Claims: Taking Control of the Process. Booz and Company Media Uploads. Retrieved from http://www.booz.com. 
Chandra, A., Nundy, S. \& Seabury, S. (2005) The Growth of Physical Medical Malpractice Payments: Evidence from the National Practitioner Data Bank. Supply Web Exclusives W5240-W5

Dansu, F. \& Yusuf, T. (2014) Effect of Claim Cost on Insurer's Profitability in Nigeria. International Journal of Business and Commerce, 3(10) 1 - 20

Diacon, S. (1983) Principles of Economics. Study Course for CIIN Subject 103s

Epetimehin, F. \& Ekundayo, O. (2012) The Impact of Risk Pricing on Profit Maximization of Insurance Companies. International Journal of Academic Research in Economics and Management Sciences, 1 (14), 21 - 35

Fiedler, M. (2018) How would Individual Market Premiums change in 2019 in a stable Policy Environment? USC-Brookings Schaeffer Initiative for Health Policy.

Fofi, G. (2016) What influence Customer Patronage of Insurance Policies: An Empirical Assessment of Socio-Economic and Demographic Determinants of Insurance Patronage in Ghana. International Review of Management and Marketing Management Research, 6 (1) $81-88$

Harrington, S. \& Niehaus, G. (2006) Risk Management and Insurance. New York: McGraw-Hill

Hartwig, R. \& Wilkinson, C. (2010) Insurance Handbook: A Guide to Insurance, What it Does and How it Works. The Insurance Information Institute

Isimoya A. (2007) Fundamentals of Insurance. Lagos: Concept Publications Limited

Kahane, Y. (1979) The Theory of Insurance Risk Premiums - A Re-Examination in the Light of Recent Developments in the Capital Market Theory. The ASTIN Bulletin, 10, 223 - 239

Lintner, J. (1965) The Evaluation of Risky Assets and the Selection of Risky Investments in Stock Portfolios and Capital Budgets. Review of Economics and Statistics, 47, 13 - 37

Michael, K. (2008) The Increasing Importance of Claims Management to Insurers. Claims Vendor Showcase, Fineos Corporation

Mossin, J. (1966) Equilibrium in a Capital Asset Market. Econometrica, 34, 768 - 783

Ramos, P. (2017) Premium Calculation in Insurance Activity. Journal of Statistics and Management Systems, 20 (1) 39-65 DOI: 10.1080/09720510.2016.1187927

Reich, J. \& Schatzberg, A. (2015) Empirical Comparisons of Malpractice Claims of Different Medical Species. Journal of Public Health Aspects, 2 (2)

Risto, H., Donham, K., Sprince, N., Reynolds, S., Philips, K. \& Zwerling, C. (2005) Effect of Premium Discount on Workers' Compensation in Agriculture in Finland. American Journal of Industrial Medicine, 48 (2) 100-109

Sharpe, W. (1964) Capital Asset Prices. Journal of Finance 19, 425 - 442

Smith, D. (2013) Understanding Commercial Insurance Premiums. A Publication of Zurich Insurance Plc.

Ukpong, M. \& Acha, I. (2017) Insurance and Economic Development in Nigeria: Co-integration and Causality Analysis. Scholedge International Journal of Management and Development, 4(4) 28-39 
Table 1: Trend movement of gross premiums and claims in the Nigerian Insurance Industry

\begin{tabular}{|l|l|l|}
\hline Year & GPI (N'm) & GCP (N'm) \\
\hline 2000 & 22531.5 & $5,629.5$ \\
\hline 2001 & 28981.3 & $6,110.5$ \\
\hline 2002 & 37765.9 & $6,856.1$ \\
\hline 2003 & 43441.8 & $9,415.2$ \\
\hline 2004 & 50100.8 & $12,084.0$ \\
\hline 2005 & 67465.7 & $12,402.4$ \\
\hline 2006 & 81583.8 & $76,276.1$ \\
\hline 2007 & 89104.9 & $25,133.2$ \\
\hline 2008 & 126470.3 & $37,412.6$ \\
\hline 2009 & 153127.1 & $61,969.2$ \\
\hline 2010 & 157336.8 & $53,815.4$ \\
\hline 2011 & 175756.8 & $60,204.8$ \\
\hline 2012 & 182172.9 & $82,454.4$ \\
\hline 2013 & 276384.8 & $101,292.5$ \\
\hline 2014 & $156,695.0$ & $51,212.4$ \\
\hline 2015 & $289,341.5$ & $111,184.1$ \\
\hline 2016 & $326,114.0$ & $145,838.4$ \\
\hline 2017 & $372,358.4$ & $186,448.0$ \\
\hline
\end{tabular}

Source: CBN Statistical Bulletin 2017; NAICOM Annual Report 2012 - 2017; NIA Digest 2013-2017

Table 2: Augmented Dicker Fuller Test Statistic

\begin{tabular}{|l|l|l|l|l|l|l|}
\hline Variables & \multicolumn{2}{|l|}{ t-statistic } & Probability & Decision \\
\cline { 2 - 6 } & Adf & $\begin{array}{l}\text { Critical } \\
\text { values at } \\
1 \% \text { level }\end{array}$ & $\begin{array}{l}\text { Critical } \\
\text { values at 5\% } \\
\text { level }\end{array}$ & $\begin{array}{l}\text { Critical values } \\
\text { at 10\% level }\end{array}$ & & \\
\hline GCP & -5.311741 & -3.920350 & -3.065585 & -2.673459 & 0.0007 & $1(1)$ \\
\hline GPI & -7.560257 & -3.920350 & -3.065585 & -2.673459 & 0.0000 & $1(1)$ \\
\hline
\end{tabular}

Source: Author's analysis from computer output 


\section{Table 3: Johansen Cointegration Test}

\begin{tabular}{|c|c|c|c|c|}
\hline $\begin{array}{l}\text { Date: } 03 / 20 / 19 \\
\text { Sample (adjust } \\
\text { Included obser } \\
\text { Trend assumpt } \\
\text { Series: GCP GF } \\
\text { Lags interval (in }\end{array}$ & $\begin{array}{l}\text { me: } 11: 22 \\
: 20022017 \\
\text { ons: } 16 \text { after } \\
\text { : Linear dete } \\
\text { st difference }\end{array}$ & $\begin{array}{l}\text { stments } \\
\text { istic trend }(r \\
\text { to } 1\end{array}$ & icted) & \\
\hline Unrestricted Co & egration Ran & st (Trace) & & \\
\hline $\begin{array}{l}\text { Hypothesized } \\
\text { No. of CE(s) }\end{array}$ & Eigenvalue & $\begin{array}{l}\text { Trace } \\
\text { Statistic }\end{array}$ & $\begin{array}{l}0.05 \\
\text { Critical Value }\end{array}$ & Prob** \\
\hline None & 0.458656 & 15.77338 & 25.87211 & 0.5108 \\
\hline At most 1 & 0.310740 & 5.954186 & 12.51798 & 0.4661 \\
\hline $\begin{array}{l}\text { Trace test indic } \\
{ }^{*} \text { denotes rejec } \\
{ }^{* *} \text { MacKinnon-H }\end{array}$ & $\begin{array}{l}\text { s no cointeg } \\
\text { ר of the hypo } \\
\text { g-Michelis (1 }\end{array}$ & $\begin{array}{l}n \text { at the } 0.05 \\
\text { s at the } 0.05 \\
p \text {-values }\end{array}$ & & \\
\hline Unrestricted Co & egration Ran & st (Maximum & genvalue) & \\
\hline $\begin{array}{l}\text { Hypothesized } \\
\text { No. of CE(s) }\end{array}$ & Eigenvalue & $\begin{array}{l}\text { Max-Eigen } \\
\text { Statistic }\end{array}$ & $\begin{array}{c}0.05 \\
\text { Critical Value }\end{array}$ & Prob.** \\
\hline None & 0.458656 & 9.819193 & 19.38704 & 0.6382 \\
\hline At most 1 & 0.310740 & 5.954186 & 12.51798 & 0.4661 \\
\hline $\begin{array}{l}\text { Max-eigenvalue } \\
{ }^{*} \text { denotes rejec } \\
{ }^{* *} \text { MacKinnon- }\end{array}$ & $\begin{array}{l}\text { tindicates } \\
\text { of the hypo } \\
\text {-Michelis (1 }\end{array}$ & $\begin{array}{l}\text { integration } \\
\text { s at the } 0.05 \\
p \text {-values }\end{array}$ & $\begin{array}{l}\text { ee } 0.05 \text { level } \\
\text { jel }\end{array}$ & \\
\hline
\end{tabular}

Source: Computer Output using E-views 10.0

Table 4: Regression Analysis

Dependent Variable: GCP

Method: Least Squares

Date: $03 / 20 / 19$ Time: $11: 50$

Sample: 20002017

Included observations: 18

\begin{tabular}{lrlll}
\hline \hline \multicolumn{1}{c}{ Variable } & Coefficient & Std. Error & t-Statistic & Prob. \\
\hline \hline G & -9339.655 & 6457.953 & -1.446225 & 0.1674 \\
\multicolumn{1}{c}{ GPI } & 0.460362 & 0.035845 & 12.84310 & 0.0000 \\
\hline \hline R-squared & 0.911575 & Mean dependent var & 58096.60 \\
Adjusted R-squared & 0.906049 & S.D. dependent var & 52038.55 \\
S.E. of regression & 15950.57 & Akaike info criterion & 22.29682 \\
Sum squared resid & $4.07 \mathrm{E}+09$ & Schwarz criterion & 22.39575 \\
Log likelihood & -198.6713 & Hannan-Quinn criter. & 22.31046 \\
F-statistic & 164.9451 & Durbin-Watson stat & 2.043652 \\
Prob(F-statistic) & 0.000000 & & & \\
\hline \hline
\end{tabular}

Source: Computer Output using E-views 10.0 